Bulgarian Academy of Sciences. Space Research and Technology Institute.

Aerospace Research in Bulgaria. 32, 2020, Sofia

DOI: https://doi.org/10.3897/arb.v32.e16

\title{
APPLICATION OF CRYOTECHNOLOGY IN THE CREATION OF SPACE FOODS FOR CREWS WORKING IN EXTREME CONDITIONS
}

\author{
Peter Getsov ${ }^{1}$, Tsvetan Tsvetkov ${ }^{1}$, Georgi Sotirov ${ }^{1}$, Iliana Nacheva ${ }^{2}$, \\ Zoya Hubenova ${ }^{1}$, Maria Doneva ${ }^{2}$, Petia Metodieva ${ }^{2}$ \\ ${ }^{1}$ Space Research and Technology Institute - Bulgarian Academy of Sciences \\ ${ }^{2}$ Institute of Cryobiology and Food Technology \\ e-mail: getsovp@space.bas.bg;director@ikht.bg
}

Keywords: Space Foods, Cryobiology, Lyophilisation.

\begin{abstract}
The article presents the achievements in the field of cryobiology and is related to the work for ESA project. Space food is a variety of food products specially formulated and processed for space flight use. Food should meet specific requirements to ensure balanced nutrition for those working in extreme conditions while being easily and safely stored, prepared and consumed in low gravity environments. It is reviewed domestic and foreign market for space foods and defined requirements to astronauts; for other users: military; extreme professions; extreme sports, for hospitals and children gardens. There are summarizes the nutritional requirements for all mentioned above group users of space foods. There is shown Bulgarian experience in research and development of space foods and comparison of the Bulgarian Space Menu.
\end{abstract}

\section{Introduction}

The intake of food is one of the most important physiological factors which is of decisive importance in sustaining the work capacity, adaptive powers and health condition of the astronauts during long space flights. The dominant negative factors encountered in the extraordinary labour and living conditions in space are weightlessness, high pressure, high radioactivity, peculiar microclimate, and great nervous and psychological stress, limited scope of movement, noise and vibrations, among others. The qualitative and quantitative sufficiency of the food is of crucial importance in helping astronauts cope with the negative processes underway in the organism under the influence of the adverse factors typical of long space flights.

Space food is a variety of food products specially formulated and processed for space flight use. Food should meet specific requirements to ensure balanced nutrition for those working in extreme conditions while being easily and safely stored, prepared and consumed in low gravity environments. Despite the 
wide variety of food and beverages consumed by astronauts, it is very important that they are provided with a nutritional formula that provides all the necessary vitamins and nutrients and guarantees the working capacity and nervous psychological resistance of the crews [1-4].

The different forms in which food is provided include the following [5, 6]:

1. Rehydratable - both commercial and internally processed freeze - dried foods are included in the NASA food provisions and then rehydrated during the mission using the potable water supply. Rehydratable foods are typically side dishes, such as spicy green beans and cornbread dressing, or cereals. ESA rehydratable products include soups, shrimp cocktail and scrambled eggs fall into this category. Ambient and hot water are available to the crew for rehydration of these items.

2. Thermostabilized - this process, also known as the retort process, heats food to a temperature that renders it free of pathogens, spoilage microorganisms, and enzyme activity. NASA thermostabilized products include pouched soups, sides, desserts, puddings, and entrees. ESA thermostabilized products include beef with mushrooms, ravioli and tuna in this way.

3. Natural form - natural form foods are commercially available, shelf stable foods. The moisture of the foods may range from low moisture (such as almonds and peanuts) to intermediate moisture (such as brownies and dried fruit), but all have reduced water activity, thus inhibiting microbial growth. These foods help to round out the menu by providing very familiar menu options, additional menu variety, and foods requiring no preparation time.

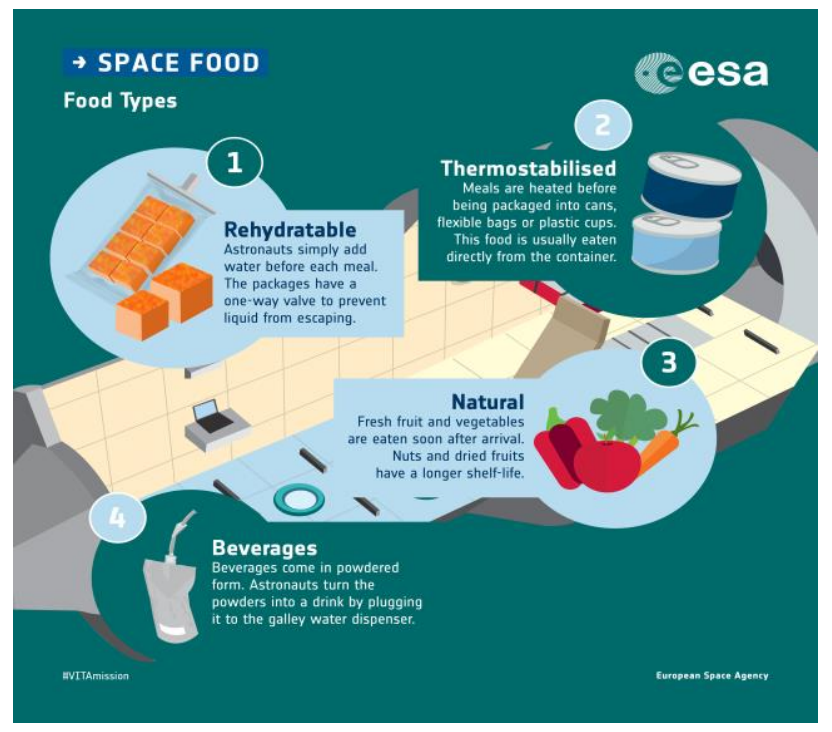


4. Beverages - the beverages currently used on the International Space Station (ISS) are either freeze-dried beverage mixes (such as coffee or tea) or flavoured drinks (such as lemonade or orange drink). The drink mixes are weighed and then vacuum sealed inside a beverage pouch. In the case of coffee or tea, sugar or powdered cream can be added to the pouch before sealing. Empty beverage pouches are also provided for drinking water $[7,8]$.

5. Extended shelf life bread products - items, such as scones, waffles, tortillas, and dinner rolls, can be formulated and packaged to give them a shelf life of up to 18 months. Like the natural form foods, breads add to menu variety and address crewmembers' desire for familiarity.

6. Fresh food - foods such as fresh fruits and vegetables, which have a short shelf life, are provided on a limited basis, more for psychological support than as a means to meet dietary requirements.

7. Irradiated - irradiation is not typically used to process foods to commercial sterility. However, NASA has received special dispensation from the Food and Drug Administration (FDA) to prepare 9 irradiated meat items to commercial sterility (FDA 2009).

\section{Space foods Bulgaria}

The Institute of Cryobiology and Food Technologies and the Space Research and Technologies Institute in Sofia are pioneered biotechnologies for the production of space foods, offering a comprehensive menu known as the Bulgarian Space Menu (BSM) to the joint Soviet-Bulgarian space flights, within the framework of the Shipka project. As a result, the Republic of Bulgaria became the third country in the world, alongside Russia and the USA, to produce space foods $[9,10]$.

Bulgaria has experience and traditions in the development of freeze-dried foods and beverages designed for space crews and people's contingents working in extreme conditions.

Lyophilisation is a process of separation of moisture from fresh produce by vacuum and low temperatures, allowing virtually completely (to 95\%) to be stored in these nutrients, vitamins, trace elements, even the original form natural flavour, taste and colour. Preserved by Lyophilisation product excludes the use of flavourings, colourings or preservatives. One of the most important advantages of this method is the small deformation of the initial product, which allows avoiding its destruction and restoring the original structure of freeze-dried products in cellular hydration. For long-term, safe and proper storage of food and organic foods that method is highly reliable and highly efficient. The high quality, convenience of storage and transportation leads to a widespread industrial development of the sublimation drying of food products. Major manufacturers of such foods are the United States, England, Canada, Denmark, France, China and 
others. The production list of most businesses includes fruit, vegetables, seafood, meat, poultry, eggs, mushrooms, tea, dairy products and ready-made culinary products. Over the last decade, cryobiotechnology enters more extensively in the manufacture of innovative products for the pharmaceutical, health, environment and other specific activities.

The BSM consists of 27 types of lyophilized foods based on meat, meat and vegetables and fruit and milk mixes; soups, main meals, desserts, Bulgarian yoghurt and fruit in the shape of quick meal and food pills. The pills are suitable for daily nutritional rations with a minimized mass of 300-500 $\mathrm{g}$ and a volume adapted to long space flights (Appendix1).

The BSM complies with modern nutritional requirements, with respect to composition and energy value, under extreme conditions during long space flights. The daily space food allowance of lyophilized foods has an energy value of $12819 \mathrm{~kJ} / 3$ 050-3 $150 \mathrm{kcal} /$ and features the following chemical composition: proteins $135 \mathrm{~g}$, fats $110 \mathrm{~g}$, carbohydrates $380 \mathrm{~g}$. The lyophilized space rations are rich in vitamins such as (3-carotene, A, the B complex, D, P, PP, C and others, mineral salts such as $\mathrm{Na}-4.5 \mathrm{~g}, \mathrm{~K}-3.0 \mathrm{~g}, \mathrm{Ca}-0.8 \mathrm{~g}, \mathrm{Mg}-0.4 \mathrm{~g}, \mathrm{Fe}-0.05 \mathrm{~g}$, $\mathrm{P}-1.7 \mathrm{~g}$, organic acids, flavins, pectin substances, live lactic acid bacteria which play the role of detoxicants and regulators of the digestive tract.

The BSM is intended for a diet of four meals a day - two snacks, lunch and supper, with an interval between the meals of between three to five hours. Consumption of the lyophilized space foods is prescribed after rehydration, at temperatures between 27 to $65{ }^{\circ} \mathrm{C}$ /except the fruit/, depending on the type of foodstuff. The durability of the space foods extends to five years and they do not contain artificial preservatives.

The BSM is characterized by the delectable traditional flavour of Bulgarian cuisine, a high content of extracts, excellent organoleptic qualities assigned foods used in space conditions where sensory response is considerably subdued because of the change in the physiological activity of the sense of taste. The strong mix of flavour and taste of Bulgarian space foods contributes to the high rate of acceptance, good digestibility and favourable physiological impact on metabolism, adaptability, immune resistance and the work capacity of astronauts. At the same time, the Bulgarian space menu ensures a maximized diet free of dullness, providing for diversity in the daily menu of the astronauts in the course of protracted space flights.

\section{The domestic and foreign market for space foods includes:}

- Astronauts;

- Teams such as military, civil defence, firefighters, high rescuers, crew and others;

- Restorative infant feeding problems, mothers, students and athletes and other International market; 
- Specialized hospitals to treat patients in the stages of medical evacuation, meals to troops operating in extreme terms.

- Extreme sports - mounting climbers, caving people and etc.

In addition to the above potential users of the innovative product markets are possible for crews working in conditions of prolonged space flight for the personnel of nuclear submarines, paratroopers, Special Forces, commandos and others.

\section{Space Food's Requirements to Astronauts}

Astronauts need the same number of calories during a spaceflight as they need on Earth. Fat, protein and carbohydrate provide energy to keep up their activities on the Space Station. Energy intake can differ for each person. The World Health Organization estimates energy requirements and issues recommendations based on a formula [11].

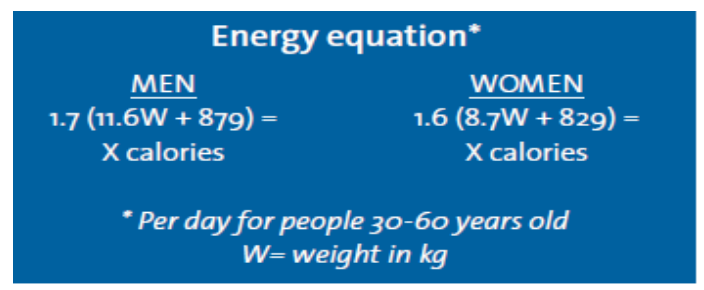

- A $80 \mathrm{~kg}$ man needs about 3000 calories a day - A $60 \mathrm{~kg}$ woman needs about 2100 calories a day

Current ISS crew members receive about $1.8 \mathrm{~kg}$ of food plus packaging per person per day. Part of this food is thermostabilized, because the thermostabilized food is still generally preferred in taste tests to freeze dried items by crew members. Since the ISS utilizes solar panels for a power source and not fuel cells that produce water as a by-product, there is no mass advantage to using freeze-dried foods. Water is now transported to the ISS for rehydration. Furthermore, contributing to the mass increase is an increase in the required caloric delivery. The required calories as stated in the mission guidelines are based on the actual caloric needs of the crewmember, which are based on body weight and height. The result is an average caloric requirement of $3000 \mathrm{kcal}(12550 \mathrm{~kJ})$ as opposed to the $2500 \mathrm{kcal}(10460 \mathrm{~kJ})$ provided to the Apollo crew. In light of these mass challenges, NASA is considering various avenues of food mass reduction while still providing the crew with adequate calories and an acceptable diet [1].

Without adequate nutrition, human performance and sustainment are endangered. Adequate nutrition has 2 components - required nutrients and supplied energy in the form of calories. Distinct health issues stem from inadequate calories and from inadequate micronutrient intake. It is important that the crewmembers are provided with the required level of nutrition throughout their missions to prevent disease. 
Table 1. Summarizes the nutritional requirements for long-duration missions

\begin{tabular}{|c|c|c|c|}
\hline Nutrients & Daily dietary intake & Nutrients & Daily dietary intake \\
\hline \multirow[t]{7}{*}{ Protein } & - $0.8 \mathrm{~g} / \mathrm{kg}$ and & \multirow[t]{2}{*}{ Thiamin } & Women: $1.1 \mathrm{mg}$ \\
\hline & \multirow{2}{*}{$\begin{array}{l}\cdot \leq 35 \% \text { of the total } \\
\text { daily energy intake } \\
\text { and }\end{array}$} & & Men: $1.2 \mathrm{mg}$ \\
\hline & & Riboflavin & $1.3 \mathrm{mg}$ \\
\hline & \multirow{4}{*}{$\begin{array}{l}\text { - } 2 \text { of } 3 \text { of the amount } \\
\text { in the form of animal } \\
\text { protein and } 1 \text { of } 3 \mathrm{in} \\
\text { the form of vegetable } \\
\text { protein }\end{array}$} & Folate & $400 \mu \mathrm{g}$ \\
\hline & & Niacin & $16 \mathrm{mg}$ niacin equivalent \\
\hline & & Biotin & $30 \mu \mathrm{g}$ \\
\hline & & \multirow{2}{*}{$\begin{array}{l}\text { Pantothenic } \\
\text { acid }\end{array}$} & \multirow[t]{2}{*}{$30 \mathrm{mg}$} \\
\hline \multirow[t]{3}{*}{ PGCarbohydrate } & \multirow{3}{*}{$\begin{array}{l}50 \% \text { to } 55 \% \text { of the } \\
\text { total daily energy } \\
\text { intake }\end{array}$} & & \\
\hline & & $\begin{array}{l}\text { Calcium } \\
\text { Phosphorus }\end{array}$ & 1200 to $2000 \mathrm{mg}$ \\
\hline & & \multirow[t]{2}{*}{ Phosphorus } & - $700 \mathrm{mg}$ and \\
\hline \multirow[t]{2}{*}{ Fat } & \multirow{2}{*}{$\begin{array}{l}25 \% \text { to } 35 \% \text { of the } \\
\text { total daily energy } \\
\text { intake }\end{array}$} & & $\bullet \cdot \leq 1.5 \times$ calcium intake \\
\hline & & \multirow[t]{3}{*}{ Magnesium } & - Women: $320 \mathrm{mg}$ \\
\hline$\Omega-6$ fatty acids & $14 \mathrm{~g}$ & & - Men: $420 \mathrm{mg}$ and \\
\hline$\Omega-3$ fatty acids & 1.1 to $1.6 \mathrm{~g}$ & & $\begin{array}{l}\cdot \leq 350 \mathrm{mg} \text { from } \\
\text { supplements only }\end{array}$ \\
\hline Saturated fat & $<7 \%$ of total calories & Fluoride & 1500 to $2300 \mathrm{mg}$ \\
\hline Trans fatty acids & $<1 \%$ of total calories & Potassium & $4.7 \mathrm{~g}$ \\
\hline Cholesterol & $<300 \mathrm{mg} / \mathrm{d}$ & Iron & 8 to $10 \mathrm{mg}$ \\
\hline Fiber & 10 to $14 \mathrm{~g} / 4187 \mathrm{~kJ}$ & Copper & 0.5 to $9 \mathrm{mg}$ \\
\hline Fluid & - 1 to $1.5 \mathrm{~mL} / 4187 \mathrm{~kJ}$ & Manganese & - Women: $1.8 \mathrm{mg}$ \\
\hline & and & & - Men: $2.3 \mathrm{mg}$ \\
\hline & $\cdot \geq 2000 \mathrm{~mL}$ & Fluoride & - Women: $3 \mathrm{mg}$ \\
\hline Vitamin A & 700 to $900 \mu \mathrm{g}$ & & - Men: 4 mg \\
\hline Vitamin D & $25 \mu \mathrm{g}$ & Zinc & $11 \mathrm{mg}$ \\
\hline Vitamin K & Women: $90 \mu \mathrm{g}$ & & \\
\hline & Men: $120 \mu \mathrm{g}$ & Selenium & 55 to $400 \mu \mathrm{g}$ \\
\hline Vitamin E & $15 \mathrm{mg}$ & & \\
\hline Vitamin C & $90 \mathrm{mg}$ & Iodine & $150 \mu \mathrm{g}$ \\
\hline Vitamin B12 & $2.4 \mu \mathrm{g}$ & & \\
\hline Vitamin B6 & $1.7 \mathrm{mg}$ & Chromium & $35 \mu \mathrm{g}$ \\
\hline
\end{tabular}

The ability of the food system to meet the nutritional requirements can be determined only when the nutritional profile of the entire space food system is known for the time at which the food is consumed.

During the development of an extra-terrestrial food system, mission resources, including mass, volume, power, crew time, and waste disposal capacity, 
must be considered. Misuse of these resources could limit mission success. Consistently, the balance of resources with other necessary mission factors-food quality or crew hygiene - is at the forefront of planning and design. The conundrum of long exploratory missions is that these missions are both resource constrained and of long duration, requiring strict adherence to nutritional guidelines. Even though food and resource utilization may be at odds, both are vital to mission success. In short, the food must provide the nutrients to sustain crew health and performance, must be acceptable throughout the course of the mission, must be safe even after cooking and processing, and must be formulated and packaged in such a way that the mass and volume are not restrictive to mission viability.

Bulgarian potential customers except astronauts are Ministry of Defence, State Agency "Civil protection", Emergency Services, and other Specialized Hospitals.

\section{Space Foods Requirements for other users}

\section{Foods Requirements for Military}

The exact determination of the energy requirements of the military personnel is linked with the implementation of scientifically grounded approaches for calculation of the total energy requirement. Each vital, work or daily human activity is connected with consumption of energy, which is supplied by the organism by means of dissolving the received nutrient substances [12-14].

The average daily energy requirement of female and male servicemen with the same functional duties and analogical physical activities is shown at Table 2.

Table 2. Average daily energy requirement of female and male servicemen with the same functional duties and analogical physical activities

\begin{tabular}{|l|c|c|c|c|l|}
\hline \multirow{2}{*}{ Physical activities } & $\begin{array}{l}\text { Duration } \\
\text { of the } \\
\text { research } \\
\text { in days }\end{array}$ & Gender & $\begin{array}{c}\text { Examined } \\
\text { persons }\end{array}$ & $\begin{array}{l}\text { Average } \\
\text { daily energy } \\
\text { requirement } \\
\text { kcal/daily }\end{array}$ & $\begin{array}{l}\text { Average daily } \\
\text { energy } \\
\text { requirement for } \\
\text { 1 kg of the body } \\
\text { weight kg.kcal- } \\
\text { 1.daily-1 }\end{array}$ \\
\hline $\begin{array}{l}\text { Continued work } \\
\text { during the training of } \\
\text { Norwegian rangers }\end{array}$ & 7 & $\mathrm{M}$ & 6 & 6678 & 93.5 \\
\hline $\begin{array}{l}\text { Field training with } \\
\text { intense physical } \\
\text { loads }\end{array}$ & 2.25 & $\mathrm{~F}$ & 4 & 5597 & 95.7 \\
\hline Physical training & 14 & $\mathrm{M}$ & 29 & 6129 & 83.0 \\
\cline { 3 - 6 } & 11 & $\mathrm{~F}$ & 20 & 4048 & 82.0 \\
\hline $\begin{array}{l}\text { Administrative } \\
\text { activities }\end{array}$ & & 10 & 2378 & 41.1 \\
\hline
\end{tabular}




\section{Foods Requirements for sailors and submariners}

Nutritional requirements of Navy Personnel are different from those of ground forces due to logistic constraints posed when being away from sea-coast.

Energy expenditure at ships was in the range of $2449-4907 \mathrm{kcal} /$ day with a mean of $3313+578 \mathrm{kcal} /$ day, while in the case of submariners, it was $3168+282(2606-3907) \mathrm{kcal} /$ day.

Energy intake in the case of sailors and submariners was not different either at hoer establishment and/or at ship/submarines. Energy intake was found to be $3518+286 \mathrm{kcal} / \mathrm{day}$. The energy contribution from carbohydrates, fats and proteins was 59.9 per cent, 27.8 per cent, and 12.3 per cent, respectively (Table 3 ) [15].

Table 3. Nutrient intake of sailors and submariners

\begin{tabular}{|lc|}
\hline Nutrients & Intake \\
\hline Energy (kcal) & $3518 \pm 286$ \\
Protein (g) & $108 \pm 25$ \\
Total Fat (g) & $109 \pm 24$ \\
Visible Fat (g) & $68 \pm 10$ \\
CHO (g) & $527 \pm 51$ \\
Vitamin A ( $\mu \mathrm{g})$ & $625 \pm 102$ \\
Vitamin C (mg) & $58 \pm 22$ \\
Thiamin (mg) & $1.7 \pm 0.15$ \\
Riboflavin (mg) & $1.6 \pm 0.3$ \\
Niacin (mg) & $33 \pm 3.7$ \\
Iron (mg) & $38.0 \pm 6.6$ \\
Calcium (mg) & $1410 \pm 156$ \\
Phosphorus (mg) & $1534 \pm 125$ \\
Sodium (mg) & $7000 \pm 330$ \\
Potassium (mg) & $2856 \pm 135$ \\
Zinc (mg) & $16.2 \pm 1.30$ \\
Copper (mg) & $2.80 \pm 0.50$ \\
& \\
Energy contribution & \\
Carbohydrates per cent & 59.9 \\
Protein (per cent) & 12.3 \\
Fat (per cent) & 27.8 \\
\hline
\end{tabular}




\section{Energy requirements for military personnel in extreme conditions}

Energy requirements in hot climate. In areas of hot climate, a person is in a state of permanent heat pressure, especially during the summer months. When the temperature of the habitat is equal to or higher than the average temperature of the body surface, evaporation of sweat is the only way to maintain the body's thermal equilibrium. Calculations show that in similar conditions for the discharge of every $4.2 \mathrm{MJ}(1000 \mathrm{kcal})$ of metabolic heat from the body surface and upper respiratory tract, at least $1725 \mathrm{~g}$ of moisture should evaporate. This moisture comes mainly through the sweat glands, which are able to secrete 10-12 and even up to 15 litters of sweat per day under heat stress conditions [16].

With many days of loss of large amounts of sweat (over 4-5 litters), the deficiency of mineral salts, especially potassium, and vitamins can be significant, which necessitates the correction of dietary rations to prevent salt depletion and devitaminization.

\section{Energy requirement under hot climatic conditions}

The analysis of the available literature imposes the conclusion, that generally the high temperature of the environment influences insignificantly on the daily energy requirements of the military personnel. A study, carried out in the desert shows, that the artillery units consume averagely $4108 \mathrm{kcal} /$ daily under average daily air temperature of $20.6{ }^{\circ} \mathrm{C}$. Similar total energy requirements (3941 kcal/daily) are observed for the infantry units in Israel, where the temperatures vary from 23 up to $31^{\circ} \mathrm{C}$. The Royal Australian Air Forces in North Australia consume about $3702 \mathrm{kcal} /$ daily, at temperatures varying from 24 to $33{ }^{\circ} \mathrm{C}$, and the reformed tasks are linked with guard and transport support of an airport [17].

The comparison between the energy requirements of the artillery, of the infantry and of the ground units from the Air Forces show, that the general energy requirements are similar to the values, observed under cooler conditions (4 $099 \mathrm{kcal} /$ daily for training at the permanent dislocation station, $3346 \mathrm{kcal} /$ daily and $3568 \mathrm{kcal} /$ daily for everyday activities of the supporting units).

One of the reasons for that, roots in the fact, that the servicemen perform their obligations more efficient in hot, dry and clear days. The energy requirements are connected mainly with the sort and the duration of the activities, which are being performed, not with the hot meteorological conditions.

\section{Energy requirements in winter and under cold climatic conditions}

Hoyt and team consider that the general energy requirement of the military personnel increases in winter and under cold climatic conditions. In the examination of the American marines in cold weather (under temperatures of the 
environment from -10 up to $5{ }^{\circ} \mathrm{C}$ ), average energy requirements of $5398 \mathrm{kcal} /$ daily are observed [18]. The general energy requirements had been around $4156 \mathrm{kcal} /$ daily in warm weather (under temperatures of the environment from 9 up to $31{ }^{\circ} \mathrm{C}$ ) for the same course at the same place, under analogical general physical and mental pressure.

\section{Energy requirements in the highlands}

It is recommended to provide personnel operating in the mountains with a diet containing up to $4500 \mathrm{kcal}$ (about $17 \mathrm{MJ}$ ). With regard to the qualitative composition, then, given the difficulties of metabolizing fat and partially proteins, they provide an increase in the carbohydrate quota, and preference is given not to one of them, but to their mixtures.

The servicemen from the American Army, located in Potosi, Bolivia at $3500-4050 \mathrm{~m}$ altitude, have had an average daily energy requirement of $3535 \mathrm{kcal}, 10$ days long, during the construction of the infrastructure [94]. These values are a little bit higher than the general energy requirements of $3463 \mathrm{kcal} /$ daily for servicemen from the engineering units, performing similar activity at a sea area.

\section{Requirements for extreme professions}

\section{Civil protection crews. On-board emergency packages}

Designed to provide rescue professional emergency services, professional emergency rescue units for civil defence, emergency situations and disaster relief when on board a ship in an emergency. The diet is a set of canned and concentrated foods per person per day and consumed with the permission of the ship's commander in case of accidents (Table 4).

Table 4. The Following Products are Included in the Food Ration

\begin{tabular}{|l|c|}
\hline \multicolumn{1}{|c|}{ Products } & Weight(g) \\
\hline Bread (biscuits) army of wheat flour 1 grade & 150 \\
\hline Canned meat-cereal and meat-vegetable & 500 \\
\hline Food concentrates briquetted, not requiring cooking & 120 \\
\hline Or Food concentrates briquetted for instant cooking & 120 \\
\hline Condensed whole milk with sugar & 90 \\
\hline Or chocolate paste & 50 \\
\hline Or dry milk & 70 \\
\hline Or dry milk drink & 70 \\
\hline Sugar & 15 \\
\hline Lollipop & 20 \\
\hline
\end{tabular}




\begin{tabular}{|l|c|}
\hline \multicolumn{1}{|c|}{ Products } & Weight $(\mathbf{g})$ \\
\hline Or sugar & 40 \\
\hline Or fruit stick & 50 \\
\hline Or fruit jam & 60 \\
\hline Instant coffee & 2 \\
\hline Black tea & 2 \\
\hline Multivitamins, coated tablets & 2 \\
\hline Plastic spoon, (pcs). & 1 \\
\hline Can opener, (pcs) & 1 \\
\hline Drinking water, canned, (ml) & 125 \\
\hline
\end{tabular}

Food And Energy Value of Food Ration - proteins 83 g; fats 92 g; carbohydrates $348 \mathrm{~g}$, Energy Value $-2552 \mathrm{kcal}$.

\section{Requirements for fire brigade crews}

This study piloted the use of an electronic activity monitor (MTI AM 7164-1.2) as a tool for estimating activity (EE(ACT), kcal day ${ }^{-1}$ ) and total (EE(TOT) kcal day ${ }^{-1}$ ) energy expenditure in wildland fire fighters during extended periods of wildland fire suppression. Ten Hot Shot fire fighters (9 men, 1 woman) volunteered to wear a MTI monitor during every work shift for 21 consecutive days. Summarizing whole-body motion data each $1 \mathrm{~min}$, the raw activity data (counts $\mathrm{min}^{-1}$ ) were transformed into units of $\mathrm{kcal} \mathrm{min}^{-1}$ using a custom computer program with standard conversion equations. $\mathrm{EE}(\mathrm{TOT})$ averaged (Mean $\pm \mathrm{SD}$ ) $4768 \pm 478 \mathrm{kcal} \mathrm{day}^{-1}$, while EE(ACT) averaged $2585 \pm 406 \mathrm{kcal} \mathrm{day}^{-1}$, neither of which differed significantly ( $\mathrm{P}=0.198$ and 0.268 , respectively) from literature values reported for Hot Shots using the doubly labelled water technique. These data suggest that the electronic activity monitor provided reasonable estimates of EE in wildland fire fighters. This study should be verified, however, with a more complete validation methodology to ensure these findings [19].

\section{Requirements for extreme sports}

\section{Caving peoples}

The impact of caving activity on body composition and hydration were assessed through bioelectrical impedance, and nutritional habits of cavers surveyed. During cave activity, measured total energy expenditure (TEE) was in the range $225 \pm 287 \mathrm{kcal} / \mathrm{h}$ for women-men $(\mathrm{MET}=4.1$ ), respectively; subjects had an energy intake from food in the range $1000 \pm 1200 \mathrm{kcal}$, thus inadequate to restore lost calories. 
Comparison of dietary intake and energy expenditure (TEE) in a normal day versus the full cave day and cave activity per se, offers interesting cues (Table 5).

Table 5. Anthropometric measurements, physiological variables, and dietary intake

\begin{tabular}{|l|c|c|c|c|}
\hline & \multicolumn{2}{|c|}{ Men } & \multicolumn{2}{c|}{ Women } \\
\hline & Mean & SD & Mean & SD \\
\hline Height $(\mathrm{m})$ & 1.7 & 0.1 & 1.6 & 0.1 \\
\hline Weight $(\mathrm{kg})$ & 73.2 & 11.7 & 55.4 & 6.0 \\
\hline BMI & 24.7 & 3.0 & 21.8 & 2.1 \\
\hline TEE $(\mathrm{kcal} / 24 \mathrm{~h})$, normal day & 3487.9 & 528.2 & 2367.3 & 316.6 \\
\hline TEE $(\mathrm{kcal} / 24 \mathrm{~h})$, cave day & 5128.5 & 862.5 & 3980.9 & 441.1 \\
\hline TEE $(\mathrm{kcal} / \mathrm{h})$, cave activity & 287.5 & 48.5 & 225.4 & 27.9 \\
\hline MET's, cave activity & 4.1 & 0.7 & 4.1 & 0.5 \\
\hline Intake $(\mathrm{kcal} / 24 \mathrm{~h})$, nomal day & 2640.7 & 673.5 & 1858.1 & 324.3 \\
\hline Intake $(\mathrm{kcal} / 24 \mathrm{~h})$, cave day & 3393.7 & 1530.3 & 2672.9 & 732.3 \\
\hline Intake $(\mathrm{kcal} / 10 \mathrm{~h})$, cave activity & 1186.8 & 473.4 & 1008.2 & 513.2 \\
\hline BMI, body mass index; MET, metabolic equivalent of task; TEE, total energy expenditure; SD, standard \\
deviation.
\end{tabular}

\section{Requirements for children gardens and hospitals}

\section{The physiological norms of nutrition of the population}

Lyophilized space foods can also be used to feed the population based on physiological nutrition norms.

Energy needs are defined as mean energy needs expressed in MJ and kcal per day for population groups age-differentiated by reference height and weight estimated for different levels of physical activity and representing the average daily requirement over a period of at least one week.

The application of the physiological norms of nutrition aims at meeting the physiological needs, achieving normal growth and development and creating prerequisites for long-term good health of the population [20].

Table 6. Average energy needs for boys and girls from 1 to 19 years of ageby age groups

\begin{tabular}{|l|l|l|l|l|}
\hline \multirow{2}{*}{$\begin{array}{c}\text { Age } \\
\text { (years) }\end{array}$} & \multicolumn{2}{|c|}{ Boys } & \multicolumn{2}{c|}{ Girls } \\
\cline { 2 - 5 } & MJ/daily & Kcal/daily & MJ/daily & Kcal/daily \\
\hline $1-<3$ & 4.36 & 1040 & 4.09 & 980 \\
\hline $3-<5$ & 5.66 & 1350 & 5.26 & 1260 \\
\hline $5-<7$ & 6.80 & 1630 & 6.32 & 1510 \\
\hline
\end{tabular}




\begin{tabular}{|l|l|l|l|l|}
\hline \multirow{2}{*}{$\begin{array}{c}\text { Age } \\
\text { (years) }\end{array}$} & \multicolumn{2}{|c|}{ Boys } & \multicolumn{2}{c|}{ Girls } \\
\cline { 2 - 5 } & MJ/daily & Kcal/daily & MJ/daily & Kcal/daily \\
\hline $7-<10$ & 7.55 & 1800 & 7.07 & 1690 \\
\hline $10-<14$ & 9.92 & 2370 & 9.35 & 2230 \\
\hline $14-<19$ & 13.12 & 3130 & 10.35 & 2470 \\
\hline
\end{tabular}

Table 7. Average adult energy needs

\begin{tabular}{|c|c|c|c|c|c|c|}
\hline $\begin{array}{c}\text { Age } \\
\text { (years) }\end{array}$ & $\begin{array}{c}\text { Body } \\
\text { weight } \\
\text { (Kg) }\end{array}$ & $\begin{array}{c}\text { Height } \\
\text { (cm) }\end{array}$ & $\begin{array}{c}\text { Low active } \\
\text { lifestyle } \\
\text { MJ } \\
\text { (ксal)/daily }\end{array}$ & $\begin{array}{c}\text { Moderately } \\
\text { active lifestyle } \\
\text { MJ } \\
\text { (ксal)/daily }\end{array}$ & $\begin{array}{c}\text { Active lifestyle } \\
\text { MJ } \\
\text { (кcal)/daily }\end{array}$ & $\begin{array}{c}\text { A very } \\
\text { active } \\
\text { lifestyle } \\
\text { MJ } \\
\text { (кcal)/daily }\end{array}$ \\
\hline & \multicolumn{6}{|c|}{ Men } \\
\hline $19-<30$ & 70 & 178 & $9.81(2344)$ & $11.21(2679)$ & $12.61(3013)$ & $14.0(3348)$ \\
\hline $30-<60$ & 72 & 176 & 9.56 (2 286) & $10.93(2612)$ & 12.29 (2 939) & 13.66 (3 265) \\
\hline $60-<75$ & 79 & 173 & $8.66(2070)$ & $9.90(2365)$ & $11.13(2661)$ & \\
\hline \multirow[t]{2}{*}{$75+$} & 68 & 171 & 8.47 (2 024) & 9.68 (2 314) & & \\
\hline & \multicolumn{6}{|c|}{ Wimen } \\
\hline $19-<30$ & 56 & 164 & $7.65(1828)$ & 8.74 (2 089) & $9.83(2350)$ & $10.93(2612)$ \\
\hline $30-<60$ & 60 & 164 & 7.63 (1 823) & $8.72(2083)$ & 9.80 (2 343) & $10.89(2604)$ \\
\hline $60-<75$ & 60 & 160 & 6.99 (1 672) & 7.99 (1 911) & $8.99(2$ 150) & \\
\hline \multirow[t]{2}{*}{$75+$} & 55 & 158 & $6.70(1600)$ & 7.65 (1 829) & & \\
\hline & \multicolumn{6}{|c|}{ Pregnancy and nursing** } \\
\hline \multirow{3}{*}{$\begin{array}{l}\text { Pregna- } \\
\text { ncy }\end{array}$} & \multirow{3}{*}{\multicolumn{2}{|c|}{ Trimester }} & I & $+0.29(+70)$ & & \\
\hline & & & & + $1.09 \mathrm{II}(+260)$ & & \\
\hline & & & III & $+2.09(+500)$ & & \\
\hline \multirow{2}{*}{ Nursing } & \multirow{2}{*}{\multicolumn{2}{|c|}{ Month }} & $0-6$ & $+2.09(+500)$ & & \\
\hline & & & & & & \\
\hline
\end{tabular}

The main customers of lyophilised products are mountaineers and athletes who need long-term shelf-life foods. And when they have gone through this 
freezing and drying, they last up to 5 years and more. Recently, consumers of this recipe are also vegetarians.

The Bulgarian Space Menu was highly praised and appreciated by the members of the Himalayan expeditions, the Transatlantic Women's Regatta, the two expeditions to the Antarctic and on many other occasions.

\section{Conclusion}

Taking into account the most common requirements, our potential customers and our long-standing experience in developing freeze-dried foods at this stage, we are continuing to study the trends in space-based food development.

The aim of the ESA project is the development and implementation of technology for astronauts and various contingents of people working in extreme conditions. This project will definitely contribute to the development of science and practice in the particular scientific field. Products developed under this project will contribute to improving the efficiency of contingent working in extreme conditions. At the same time the results of the experiments will serve as the basis for new theoretical and experimental research in cryobiology and contribute to its development.

\section{Acknowledgements}

We hereby would like to thank to the ESA for supporting generously ESA project titled "Development and application of technology for production of space food's modules for crews working in extreme conditions".

\section{References}

1. Billock, J. The Dark Side of the Spoon: What Astronauts Eat in Space. Serious Eats. Serious Eats, 18 June 2015. (Accessed on 19 January 2016).

2. "Meals Ready to Eat: Expedition 44 Crew Members Sample Leafy Greens Grown on Space Station." NASA. NASA, 7 August 2015. (Accessed on 5 February 2016).

3. Zwart, S., Kloeris, V., Perchonok, M., Braby, L., and Smith, S. M. Assessment of Nutrient Stability in Foods from the Space Food System after Long-Duration Spaceflight on the ISS. Journal of Food Science, 2009, 74, 209-17.

4. Benson, C. D. and W. D. Compton. Living and Working in Space: A History of Skylab. NASA publication SP-4208.

5. Cooper, M., Gr. Douglas, and M. Perchonok, Developing the NASA Food System for Long -Duration Missions, March 2011 Journal of Food Science 76, 2, R40-8, DOI:10.1111/j.1750-3841.2010.01982.x.

6. SPACE FOOD, Astronaut nutrition, ESA production, 2017, hsocom@esa.int

7. Casaburri, A., Gardner, C. A. Space Food and Nutrition. Educator's Guide. NASA. Washington, D.C. 1999.

8. Evans, J. Space Farming. C\&I Agriculture, 2015, 10, $20-23$. 
9. Doneva, M., 1. Nacheva, P, Metodieva, Application of cryobiotechnologies for development of lyophilized polyenzyme complexes, Bulgarian Journal of Agricultural Science, 2014, 20, 6, 1401-05.

10. Vassilev, V., Space Sector Activities in Bulgaria, Natal, Brazil, 2018, www.castra.org

11. "Food for Space Flight" NASA. URL: http://spaceflight.nasa.gov/shuttle/reference/factsheets/food.html.

12. Nichev, N. Energy requirement of the military personnel. International Conference “Knowledge-Based Organization". 2018, XXIV, 2, 338-344, DOI:10.1515/kbo2018-0112.

13. Tharion, W. J. et al. Energy requirements of military personnel. Appetite, 2005, 44, 47-65.

14. Hoyt, R. W., Jones, T. E., Stein, T. P., McAninch, G. W., Lieberman, H. R., Askew, E. W., and Cymerman, A. Doubly labelled water measurement of human energy expenditure during strenuous exercise. Journal of Applied Physiology, 1991, 71, 16-22.

15. Singh, V. K., A., A. Dutta, V. Shukla, P. Vats, and S. N. Singh. Energy Expenditure and Nutritional Status of Sailors and Submarine Crew of the Indian Navy. Defence Science Journal, 2011, 61, 6, 540-544, DOI:10.14429/dsj.61.930.

16. Lane, H. W., Bourland, C., Barrett, A., Heer, M., and Smith, S. M. The Role of Nutritional Research in the Success of Human Space Flight. Advances in Nutrition, 2013, 4, 521-23.

17. McPhee, I. J, and Charles, J. Human health and performance risks of space exploration missions: evidence reviewed by the NASA Human Research Program (PDF). Johnson Space Center, Houston: National Aeronautics and Space Administration, Lyndon B. Johnson Space Center, 4-5. ISBN 978-0160846342.

18. Estimating energy expenditure in wild land fire fighters using a physical activity monitor. URL:https://www.ncbi.nlm.nih.gov/pubmed/12236649.

19. Antoni, G, E. Marini, N. Curreli , V. Tuveri, O. Comandini, S. Cabras, S. Gabba, C. Madeddu, A. Crisafulli, and A. C. Rinaldi. Energy expenditure in caving. PLOS ONE, 2017, DOI:10.1371/journal.pone.0170853.

20. BG Ministry Health Care -ORDINANCE No. 1 of 22 January 2018 about the physiological norms of nutrition of the population. http://www.mh.government.bg/ media/filer_public/2018/02/13/naredba1-22-01-2018-fiziologicni-normi-hranenenaselenie.pdf. 


\title{
ПРИЛОЖЕНИЕ НА КРИОТЕХНОЛОГИЯТА ПРИ СЪЗДАВАНЕ НА КОСМИЧЕСКИ ХРАНИ ЗА ЕКИПАЖИ, РАБОТЕЩИ В ЕКСТРЕМНИ УСЛОВИЯ
}

\author{
П. Гецов, Ц. Цветков, Г. Сотиров, И. Начева, З. Хубенова, \\ М. Донева, П. Методиева
}

\begin{abstract}
Резюме
Статията представя постиженията в областта на криобиологията и е свързана с работата на авторите по проект с ЕКА. Космическата храна е разнообразие от хранителни продукти, специално създадени и обработени за използване в космически полети. Тази храна трябва да отговаря на редица специфични изисквания, за да може да осигури балансирано хранене за работещите в екстремни условия, като същевременно лесно и безопасно се съхранява, приготвя и консумира в среда с ниска гравитация. Направен е преглед на вътрешния и чуждестранен пазар на космически храни. Определени са изискванията към астронавтите, както и за други потенциални потребители: военни; хора с екстремни професии; за екстремни спортове, за болници и детски градини. Дадени са обобщени хранителни изисквания за всички споменати по-горе групи потребители на космически храни. Показан е българският опит в изследването и разработването на космическите храни и създаденото българско космическо меню.
\end{abstract}

